\title{
Engineering Properties and Application of Cement-Based Fly Ash Blocks
}

R. Huang

Department of Harbor \& River Engineering National Taiwan Ocean University Keelung, Taiwan, R. O. C.

\section{J.J. Chang}

Department of Harbor \& River Engineering National Taiwan Ocean University Keelung, Taiwan, R. O. C.

W. Yeih

Department of Harbor \& River Engineering National Taiwan Ocean University Keelung, Taiwan, R. O. C.

Follow this and additional works at: https://jmstt.ntou.edu.tw/journal

Part of the Civil and Environmental Engineering Commons

\section{Recommended Citation}

Huang, R.; Chang, J.J.; and Yeih, W. (1995) "Engineering Properties and Application of Cement-Based Fly Ash Blocks," Journal of Marine Science and Technology. Vol. 3: Iss. 1, Article 7.

DOI: $10.51400 / 2709-6998.2505$

Available at: https://jmstt.ntou.edu.tw/journal/vol3/iss1/7

This Research Article is brought to you for free and open access by Journal of Marine Science and Technology. It has been accepted for inclusion in Journal of Marine Science and Technology by an authorized editor of Journal of Marine Science and Technology. 


\title{
ENGINEERING PROPERTIES AND APPLICATION OF CEMENT-BASED FLY ASH BLOCKS
}

\author{
R. Huang, J.J. Chang, and W. Yeih \\ Department of Harbor \& River Engineering \\ National Taiwan Ocean University \\ Keelung, Taiwan, R. O.C.
}

Key words: fly ash, environmental protection, properties, strength.

\begin{abstract}
Under the consideration of environmental protection, direct disposal of coal ash is not acceptable. It is required to solidify fly ash before ocean disposal or land disposal. The objective of this study is to investigate the properties and the possible applications of the solid blocks produced from fly ash. Thirty-six mixes have been proportioned using different cementing materials such as portland cement, lime, sludge treatment compound, and industrial silica slag. Extensive laboratory studies have been conducted to evaluate the block properties such as compressive strength, tensile strength, abrasion resistance, and soundness. In addition, the possible engineering application is also evaluated.

Test results show that (1) portland cement is the most possible cementing material for solidifying fly ash, and the use of lime, silica fume and sludge treatment Compound as partial replacement for cement may improve the properties of the solid blocks; (2) natural sand used as part of mixes may improve the strength and durability of the solid blocks; (3) the leaching rate of metals is low so that the solid blocks can be environmentally acceptable in the seawater; (4) based on the laboratory observations, the fly ash blocks of this study are potential construction materials for marine engineering.
\end{abstract}

\section{INTRODUCTION}

In last two decades, the coal combustion in Taiwan has been dramatically increased because of the increasing demand of electricity [1]. Due to the shortage of crude oil and the fear of nuclear disaster, coal-fired electric power plants are expected to cons ume large amount of coal to meet the demand of electric utilities in the future. Coal ashes are the coal combustion by-products. Most of coal ashes are fly ash. In Taiwan, nearly 1.3 million metric tons of ash were produced in 1989. Less than forty percent of fly ash production was utilized. The potential problem of coal ash disposal becomes more serious. In the past, direct ocean disposal or land-based disposal could be effective to solve the ash problem. Recently, due to the possible detrimental impact on the environment, direct disposal of coal ashes is restricted by the Environmental Protection Authorities [2]. It is required to solidify fly ash before ocean or land disposal. However, better solution for ash problem is to raise the percentage of engineering application, especially in the road construction and the building trade. The technology development of civil engineering will determine the consumption of the increasing amount of fly ash [2].

Nowadays the application of fly ash is mainly on cement, concrete, and road construction $[3,4]$. However, the amount of fly ash consumption is still not enough to solve the problem of treatment of fly ash. A large-scale alternative application is to solidify great amount of fly ash with other industrial waste materials [5]. Any shape can be cast for various types of application such as artificial reefs and building blocks. This possible method may satisfy the environmental restrictions on ocean disposal imposed by the authorities (the compressive strength of solid block for ocean or land disposal should be at least $100 \mathrm{kgf} / \mathrm{cm}^{2}$ ) and solve the disposal problem of fly ash. In addition, utilization of other industrial waste materials may save lots of energy and further reduce the environmental impact [6]. The solidifi- 
cation of fly ash can be achieved by use of pozzolanic properties [7]. The solidified fly ash blocks may be used as artificial reef or other building materials. The cementing materials and manufacturing procedures were investigated. The overall objective of this study is to explore the properties and possible applications of the solid blocks produced from fly ash.

\section{EXPERIMENTAL DESIGN}

The experiments were designed to determine the strengths of fly ash blocks and the environmental acceptability. Thirty-six mixes have been proportioned to determine the influence of cementing materials and fly ash replacement percentage on mortar strengths. Ordinary portland cement, silica fume, sludge treatment compound, and industrial silica slag were used as part of cementing materials. For improving the workability, type F superplasticizers was applied to the mixes. The mix design was based on ASTM standard C109. The water/cementitious material ratio was kept at a constant of 0.58 and fine aggregate/cementitious materials ratio was 2.75. Details of mix proportions are presented in Table 1. Based on the strength results and economical consideration, nine mixes as shown in Table 2 were selected to investigate the possible engineering application of fly ash.

\section{MATERIALS}

Fly ash produced from bituminous coal which conformed to the specifications of class $F$ according to ASTM standards C618 was utilized in this study. The characteristics of fly ash is presented in Table 3. The properties of cementing materials which includes sludge treatment compound, industrial silica slag, silica fume are tabulated in Table 4 through Table 6 . The specific gravity of lime was 2.41 .

\section{TESTING METHODS AND RESULTS}

\section{Compressive Strength}

Two types of specimens were used: $5-\mathrm{cm}$ cube for group A through I and $10 \times 20 \mathrm{~cm}$ cylinders for group AC. Specimens were cast and cured according to ASTM standard method (ASTM C109, C39). A $100-$ metric ton universal testing machine was used. Compressive strengths were determined at ages $3,7,14,28$, and 90 days respectively. Testing results are presented in Table 7. Fig. 1 through Fig. 9 illustrate the influence of cementing materials and the amount of fly ash replacement on the compressive strength. It appears that the use of lime, silica fume and sludge treatment agent compound partial cementing materials may improve the strength of solid block of proper fly ash replacement for natural sand.

\section{Flexural Strength}

Mortar flexural strength were determined according to ASTM standard method for group A through I. Testing results are illustrated in Fig.10. The ratio of flexural strength to compressive strength was between 0.25 and 0.32 . F or group AC, ASTM standard test method for concrete was applied to determine the flexural strength of the specimens. In addition, splitting tensile strength was measured for this group according to ASTM standard C496. Table 7 shows that the ratio of flexural strength to compressive strength is between 0.16 and 0.19 and the ratio of splitting tensile strength to compressive strength is between 0.1 and 0.13 .

\section{Drying Shrinkage}

Prismatic specimens with a dimension of $2.5 \mathrm{~cm}$ $\times 2.5 \mathrm{~cm} \times 28.5 \mathrm{~cm}$ were used to determine the drying shrinkage according to the ASTM standard C157-80. The specimens were kept in an environmental-controlled chamber with a constant te mperature of $23 \pm 1{ }^{\circ} \mathrm{C}$ and a relative humidity of $50 \%$. The shrinkage deformations at various time are plotted in Fig.11.

\section{Leaching of the Block's Soluble Components}

After 28-day moist curing, specimens were immersed into seawater which had a double volume of the specimens for five months. The seawater of different specimen immersion was sampled and analyz ed for $\mathrm{Fe}, \mathrm{Mn}, \mathrm{Zn}, \mathrm{Ca}, \mathrm{Cr}$ using the atomic absorption spectrophotometry with an accuracy of $0.1 \mathrm{ppm}$. No significant difference was found in comparison with the control sample. However, the $\mathrm{pH}$ value appeared higher in the water in which fly ash specimens were immersed.

\section{Abrasion Resistance}

The abrasion resistance of the testing materials was determined using sandblasting method (ASTM C418-81). The abrasion coefficients were calculated and plotted as bar charts in Fig. 12. It appears that the slag replacement for natural sand in the mix has better abrasion resistance.

\section{CONCLUSIONS}

Based on the laboratory testing results, the following conclusions may by drawn.

1. Portland cement is the most possible cementing material for fly ash block. Proper use of lime, silica fume and sludge treatment agent may improve the strength of fly ash blocks. 
Table 1a. Mix Proportions

\begin{tabular}{llllll} 
Mix No. & SF & FA & & \multicolumn{2}{c}{ Mix Proportions $\left(\mathrm{kg} / \mathrm{m}^{3}\right)$} \\
$+\mathrm{FA}$ & Water & Cement & Silica $\quad$ Fly Ash
\end{tabular}

\begin{tabular}{lrrrrrrrr} 
& $(\%)$ & $(\%)$ & $(W)$ & (C) & \multicolumn{1}{c}{ (S) } & (FA) & \multicolumn{1}{c}{ (S) } & (SP) \\
\hline A1 & 0 & 0 & 296 & 510 & 0 & 0 & 1403 & 5.1 \\
A2 & 0 & 40 & 353 & 434 & 0 & 478 & 717 & 6.5 \\
A3 & 0 & 70 & 385 & 391 & 0 & 752 & 322 & 6.6 \\
A4 & 0 & 100 & 412 & 355 & 0 & 976 & 0 & 7.1 \\
B1 & 5 & 0 & 296 & 485 & 25.5 & 0 & 1405 & 5.1 \\
B2 & 5 & 40 & 351 & 411 & 21.6 & 479 & 714 & 6.5 \\
B3 & 5 & 70 & 384 & 370 & 19.5 & 750 & 21 & 6.6 \\
B4 & 5 & 100 & 411 & 336 & 17.7 & 974 & 0 & 7.1 \\
C1 & 10 & 0 & 294 & 456 & 50.7 & 0 & 1394 & 5.1 \\
C2 & 10 & 40 & 350 & 388 & 43.1 & 474 & 712 & 6.5 \\
C3 & 10 & 70 & 383 & 349 & 38.8 & 747 & 320 & 6.6 \\
C4 & 10 & 100 & 409 & 318 & 35.3 & 970 & 0 & 7.1 \\
\hline
\end{tabular}

Table 1b. Mix Proportions

\begin{tabular}{llllllll} 
& Mix No. & ISS & FA & \multicolumn{4}{c}{ Mix Proportions $\left(\mathrm{kg} / \mathrm{m}^{3}\right)$} \\
& S+FA & Water & Cement & Silica & Fly Ash & Natural & Supeplasticizer
\end{tabular}

\begin{tabular}{|c|c|c|c|c|c|c|c|c|}
\hline & $(\%)$ & (\%) & (W) & (C) & $\begin{array}{c}\text { Fume } \\
\text { (S) }\end{array}$ & (FA) & $\begin{array}{c}\text { Sand } \\
\text { (S) }\end{array}$ & (SP) \\
\hline$\overline{\mathrm{D} 1}$ & 5 & 0 & 296 & 485 & 25.5 & 0 & 1404 & 5.1 \\
\hline D2 & 5 & 40 & 352 & 412 & 21.6 & 477 & 716 & 6.5 \\
\hline D3 & 5 & 70 & 385 & 371 & 19.5 & 752 & 322 & 6.6 \\
\hline D4 & 5 & 100 & 412 & 337 & 17.7 & 975 & 0 & 7.1 \\
\hline E1 & 10 & 0 & 296 & 459 & 51 & 0 & 1403 & 5.1 \\
\hline E2 & 10 & 40 & 352 & 390 & 43.4 & 477 & 716 & 6.5 \\
\hline E3 & 10 & 70 & 385 & 351 & 39 & 751 & 322 & 6.6 \\
\hline E4 & 10 & 100 & 411 & 319. & 35.5 & 975 & 0 & 7.1 \\
\hline
\end{tabular}

Table 1c. Mix Proportions

\begin{tabular}{|c|c|c|c|c|c|c|c|c|}
\hline \multirow[b]{2}{*}{ Mix No. } & \multirow{2}{*}{$\begin{array}{l}\frac{\mathrm{L}}{\mathrm{C}+\mathrm{L}} \\
(\%)\end{array}$} & \multirow{2}{*}{$\begin{array}{c}\frac{F A}{S+F A} \\
(\%)\end{array}$} & \multicolumn{5}{|c|}{ Mix Proportions $\left(\mathrm{kg} / \mathrm{m}^{3}\right)$} & \multirow[b]{2}{*}{$\begin{array}{c}\text { Supeplasticizer } \\
\text { (SP) }\end{array}$} \\
\hline & & & $\begin{array}{l}\text { Water } \\
\text { (W) }\end{array}$ & $\begin{array}{l}\text { Cement } \\
\text { (C) }\end{array}$ & $\begin{array}{c}\text { Silica } \\
\text { Fume } \\
\text { (S) }\end{array}$ & $\begin{array}{c}\text { Fly Ash } \\
\text { (FA) }\end{array}$ & $\begin{array}{l}\text { Natural } \\
\text { Sand } \\
\text { (S) }\end{array}$ & \\
\hline F1 & 5 & 0 & 296 & 484 & 25.5 & 0 & 1402 & 5.1 \\
\hline F2 & 5 & 40 & 353 & 412 & 21.6 & 477 & 715 & 6.5 \\
\hline F3 & 5 & 70 & 385 & 371 & 19.5 & 752 & 322 & 6.6 \\
\hline F4 & 5 & 100 & 412 & 337 & 17.7 & 975 & 0 & 7.1 \\
\hline G1 & 10 & 0 & 296 & 457 & 51 & 0 & 1389 & 5.1 \\
\hline G2 & 10 & 40 & 351 & 389 & 43.4 & 476 & 714 & 6.5 \\
\hline G3 & 10 & 70 & 384 & 350 & 38.9 & 749 & 321 & 6.6 \\
\hline G4 & 10 & 100 & 410 & 318 & 35.4 & 973 & 0 & 7.1 \\
\hline
\end{tabular}

Table 1d. Mix Proportions

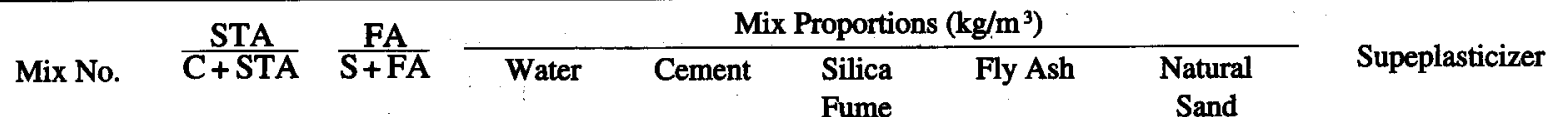

\begin{tabular}{rrrrrrrrr} 
& $(\%)$ & $(\%)$ & $($ W & $($ C) & $($ S $)$ & (FA) & \multicolumn{1}{c}{$($ S $)$} & (SP) \\
\hline H1 & 5 & 0 & 296 & 485 & 25.6 & 0 & 1405 & 5.1 \\
H2 & 5 & 40 & 353 & 410 & 21.7 & 478 & 717 & 6.5 \\
H3 & 5 & 70 & 385 & 371 & 19.5 & 752 & 32 & 6.6 \\
H4 & 5 & 100 & 412 & 337 & 17.8 & 976 & 0 & 7.1 \\
I1 & 10 & 0 & 296 & 460 & 51 & 0 & 1705 & 5.1 \\
I2 & 10 & 40 & 353 & 391 & 43.4 & 479 & 717 & 6.5 \\
I3 & 10 & 70 & 385 & 352 & 39.1 & 750 & 322 & 6.6 \\
I4 & 10 & 100 & 412 & 320 & 35.5 & 974 & 0 & 7.1 \\
\hline
\end{tabular}


Table 2. Mix Proportions per Cubic Meter

Tap Water, $\mathrm{Kg}$

Cement, $\mathrm{Kg}$

Fly Ash (Class F), Kg

Lime, $\mathrm{Kg}$

Copper Slag, Kg

Bottem Ash, $\mathrm{Kg}$

Sludge Treatment Agent, $\mathrm{Kg}$

Silica Fume, Kg

Sludge Treatment Agent, $\mathrm{Kg}$

Silica Fume, $\mathrm{Kg}$

Nature Sand, $\mathrm{Kg}$

Crush Stone, $\mathrm{Kg}$

Slump, Cm

\section{Table 2. Mix Proportions per Cubic Meter}

\begin{tabular}{ccccccccc}
\hline AC1 & AC2 & AC3 & AC4 & AC5 & AC6 & AC7 & AC8 & AC9 \\
486 & 446 & 494 & 481 & 462 & 439 & 466 & 511 & 429 \\
173 & 320 & 177 & 172 & 247 & 235 & 271 & 244 & 248 \\
694 & 765 & 706 & 687 & 741 & 704 & 876 & 790 & 739 \\
116 & - & 125 & 115 & - & - & - & - & - \\
- & - & 187 & - & 329 & - & - & - & - \\
- & - & - & 172 & - & 313 & - & - & - \\
- & - & - & - & - & - & 48 & - & - \\
- & - & - & - & - & - & - & 43 & - \\
173 & 193 & - & - & - & - & - & - & - \\
- & - & - & - & - & - & - & - & 328 \\
12.4 & 7.8 & 8.9 & 8 & 12.1 & 5.8 & 4.3 & 8.3 & 6.3 \\
\hline
\end{tabular}

Table 3. Chemical and Physical Properties of Fly Ash

\begin{tabular}{llrlr}
\hline \multicolumn{2}{c}{ Chemical Properties } & \multicolumn{3}{l}{ Physical Properties } \\
\hline $\mathrm{SiO}_{2}+\mathrm{Al}_{2} \mathrm{O}_{3}+\mathrm{Fe}_{2} \mathrm{O}_{3}$ & $(\%)$ & 86.94 & Specific Gravity & 2.06 \\
$\mathrm{CaO}$ & $(\%)$ & 0.45 & Moisture Content(\%) & 0.53 \\
$\mathrm{MgO}$ & $(\%)$ & 0.40 & Fineness: No. 325(\%) & 13.80 \\
$\mathrm{~K}_{2} \mathrm{O}$ & $(\%)$ & 1.07 & L.O.I. & 7.50 \\
$\mathrm{Na}_{2} \mathrm{O}$ & $(\%)$ & 0.27 & & \\
\hline
\end{tabular}

Table 4. Chemical and Physical Properties of Sludge treatment Agent

\begin{tabular}{llrlr}
\hline Chemical Properties & & \multicolumn{3}{l}{ Physical Properties } \\
$\mathrm{SiO}_{2}$ & $(\%)$ & 25.08 & Air Content of Motar (\%) & 4.0 \\
$\mathrm{Al}_{2} \mathrm{O}_{3}$ & $(\%)$ & 11.36 & Fineness (Blaine), $\mathrm{cm}^{2} / \mathrm{g}$ & 4220 \\
$\mathrm{Fe}_{2} \mathrm{O}_{3}$ & $(\%)$ & 2.14 & Compr. Strength, kgf/cm & \\
$\mathrm{CaO}$ & $(\%)$ & 51.34 & 3-day & 181 \\
$\mathrm{MgO}$ & $(\%)$ & 4.07 & 7-day & 300 \\
$\mathrm{SO}_{3}$ & $(\%)$ & 3.33 & 28-day & 446 \\
L.O.O. & $(\%)$ & 1.79 & Time of Setting (Vicat test) & \\
& & & Inital Set (hr:min) & $2: 00$ \\
& & & Final Set (hr:min) & $3: 30$ \\
\hline
\end{tabular}

Table 5. Chemical Properties of Industrial Slica Fume

\begin{tabular}{llrlrl}
\hline \multicolumn{7}{c}{ Chemical Properties } \\
\hline $\mathrm{SiO}_{2}$ & $(\%)$ & 55.94 & $\mathrm{~K}_{2} \mathrm{O}$ & $(\%)$ & 2.47 \\
$\mathrm{Al}_{2} \mathrm{O}_{3}$ & $(\%)$ & 16.30 & $\mathrm{Na}_{2} \mathrm{O}$ & $(\%)$ & 0.63 \\
$\mathrm{Fe}_{2} \mathrm{O}_{3}$ & $(\%)$ & 10.76 & $\mathrm{SiO}_{2}$ & $(\%)$ & 0.33 \\
$\mathrm{CaO}$ & $(\%)$ & 6.10 & Moisture Content (\%) & 5.50 \\
$\mathrm{MgO}$ & $(\%)$ & 1.25 & L.O.I. & $(\%)$ & \\
\hline
\end{tabular}

Table 6. Chemical and Physical Properties of Slica Fume

\begin{tabular}{llrll}
\hline Chemical Properties & & \multicolumn{3}{l}{ Physical Properties } \\
$\mathrm{SiO}_{2}$ & $(\%)$ & 94.0 & Specific Gravity & 2.09 \\
$\mathrm{C}$ & $(\%)$ & 1.5 & Fineness (Blaine), $\mathrm{m}^{2} / \mathrm{g}$ & 20 \\
$\mathrm{Fe}_{2} \mathrm{O}_{3}$ & $(\%)$ & 0.4 & Fineness: No. 325 (\%) & 0.10 \\
$\mathrm{Al}_{2} \mathrm{O}_{3}$ & $(\%)$ & 0.6 & pH Value & 7 \\
$\mathrm{CaO}$ & $(\%)$ & 0.3 & Density, $\mathrm{Kg} / \mathrm{m}^{3}$ & 250 \\
$\mathrm{MgO}$ & $(\%)$ & 0.8 & & \\
$\mathrm{~S} \mathrm{O}$ & $(\%)$ & 1.0 & & \\
L.O.O.(950 & $(\%)$ & 1.5 & & \\
\hline
\end{tabular}


Table 7. Strengths of Fly Ash Blocks

\begin{tabular}{|c|c|c|c|c|c|c|c|}
\hline \multirow{2}{*}{$\begin{array}{l}\text { Mix } \\
\text { No. }\end{array}$} & \multicolumn{5}{|c|}{ Compressive Strength $\left(\mathrm{Kgf} / \mathrm{cm}^{2}\right)$} & \multirow{2}{*}{$\begin{array}{l}\text { Flexural } \\
\text { Strength } \\
\text { (28-day) }\end{array}$} & \multirow{2}{*}{$\begin{array}{l}\text { Splitting Tensile } \\
\text { Strength } \\
\text { (28-day) }\end{array}$} \\
\hline & 3-day & 7-day & 14-day & 28-day & 90-day & & \\
\hline A1 & 193.9 & 203.7 & 233.5 & 248.0 & 266.7 & 64.2 & -- \\
\hline A2 & 137.9 & 177.6 & 242.1 & 273.2 & 324.3 & 68.2 & -- \\
\hline A3 & 106.7 & 126.4 & 161.7 & 197.5 & 222.2 & 58.3 & -- \\
\hline A4 & 42.4 & 80.1 & 108.8 & 158.2 & 181.1 & 48.2 & -- \\
\hline B1 & 180.1 & 230.8 & 251.3 & 260.8 & 296.1 & - & -- \\
\hline B2 & 146.0 & 187.6 & 237.6 & 261.1 & 290.7 & - & - \\
\hline B3 & 97.6 & 127.4 & 158.1 & 209.2 & 221.3 & -- & -- \\
\hline B4 & 53.9 & 78.3 & 135.3 & 169.9 & 192.0 & -- & -- \\
\hline $\mathrm{C} 1$ & 178.4 & 219.9 & 248.2 & 265.9 & 348.5 & -- & -- \\
\hline $\mathrm{C} 2$ & 123.3 & 151.2 & 211.4 & 250.2 & 342.2 & -- & -- \\
\hline $\mathrm{C} 3$ & 85.1 & 122.2 & 186.4 & 247.3 & 278.8 & 68.7 & -- \\
\hline $\mathrm{C} 4$ & 62.5 & 92.8 & 136.1 & 187.7 & 202.5 & 51.1 & -- \\
\hline D1 & 188.0 & 225.1 & 247.5 & 255.6 & 281.7 & -- & -- \\
\hline D2 & 141.6 & 178.4 & 243.2 & 252.4 & 346.6 & - & -- \\
\hline D3 & 82.8 & 109.6 & 153.6 & 203.2 & 232.4 & -- & -- \\
\hline D4 & 43.1 & 77.6 & 111.8 & 181.6 & 197.1 & 43.9 & -- \\
\hline E1 & 183.9 & 197.9 & 240.1 & 249.8 & 273.3 & -- & -- \\
\hline E2 & 136.9 & 155.6 & 224.1 & 252.7 & 298.7 & -- & -- \\
\hline E3 & 79.0 & 99.4 & 144.1 & 195.1 & 251.9 & - & -- \\
\hline $\mathrm{E} 4$ & 26.8 & 67.6 & 99.7 & 153.1 & 181.9 & -- & -- \\
\hline F1 & 157.5 & 186.3 & 203.4 & 275.5 & 327.8 & 88.6 & -- \\
\hline $\mathrm{F} 2$ & 149.6 & 177.4 & 235.2 & 277.7 & 362.1 & 69.1 & -- \\
\hline F3 & 92.4 & 135.8 & 160.8 & 222.7 & 269.7 & 60.2 & -- \\
\hline F4 & 60.7 & 89.6 & 113.2 & 162.1 & 190.1 & -- & -- \\
\hline G1 & 164.8 & 189.9 & 229.4 & 245.6 & 268.4 & -- & -- \\
\hline G2 & 143.9 & 155.2 & 235.2 & 267.3 & 323.5 & -- & -- \\
\hline G3 & 84.0 & 117.7 & 180.9 & 219.9 & 259.2 & -- & -- \\
\hline G4 & 45.8 & 86.4 & 98.1 & 161.9 & 214.2 & -- & - \\
\hline H1 & 178.2 & 203.8 & 234.0 & 272.3 & 313.2 & -- & -- \\
\hline $\mathrm{H} 2$ & 141.9 & 191.4 & 245.2 & 300.1 & 367.9 & 84.3 & - \\
\hline $\mathrm{H} 3$ & 72.8 & 130.7 & 173.7 & 197.6 & 259.6 & -- & -- \\
\hline $\mathrm{H} 4$ & 37.5 & 87.5 & 122.8 & 153.1 & 177.7 & -- & - \\
\hline I1 & 181.5 & 232.7 & 280.5 & 312.6 & 357.9 & 97.1 & -- \\
\hline 12 & 135.5 & 182.1 & 241.4 & 271.9 & 386.4 & -- & - \\
\hline $\mathrm{I} 3$ & 75.2 & 126.9 & 175.9 & 215.3 & 236.8 & -- & -- \\
\hline $\mathrm{I} 4$ & 34.1 & 80.1 & 99.9 & 169.2 & 182.7 & -- & -- \\
\hline $\mathrm{AC} 1$ & 19.4 & 36.6 & -- & 79.6 & 176.2 & 13.7 & 9.9 \\
\hline $\mathrm{AC} 2$ & 53.4 & 65.8 & -- & 20.6 & 203.5 & 20.4 & 12.8 \\
\hline AC3 & 20.4 & 30.2 & -- & 90.0 & 180.5 & 15.7 & 10.8 \\
\hline $\mathrm{AC} 4$ & 24.4 & 43.6 & -- & 78.9 & 178.0 & 14.6 & 10.1 \\
\hline AC5 & 26.0 & 47.8 & -- & 08.0 & 193.1 & 19.8 & 12.2 \\
\hline AC6 & 36.6 & 60.3 & -- & 98.5 & 200.3 & 16.7 & 11.2 \\
\hline $\mathrm{AC} 7$ & 23.4 & 52.4 & -- & 81.7 & 183.2 & 12.7 & 10.3 \\
\hline AC8 & 16.6 & 38.0 & -- & 85.2 & 196.9 & 13.6 & 10.5 \\
\hline AC9 & 36.4 & 50.8 & -- & 13.4 & 198.2 & 19.2 & 12.5 \\
\hline
\end{tabular}




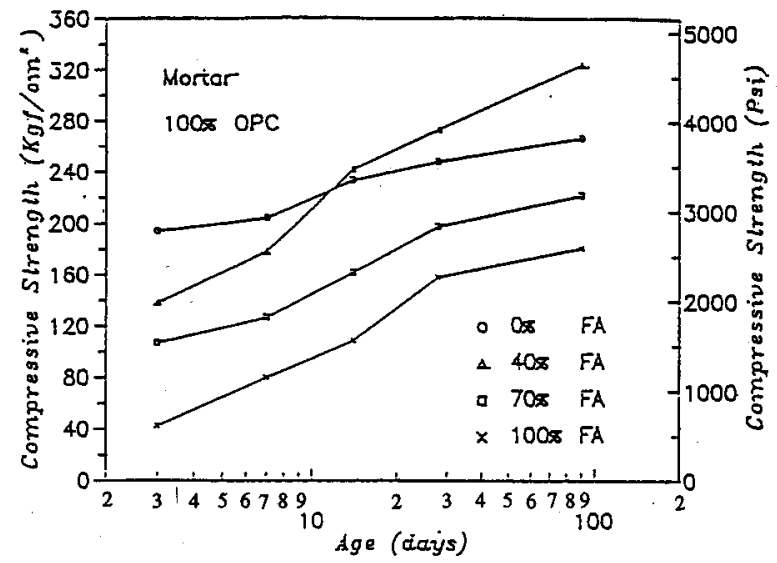

Fig. 1. Compressive Strengths of Motars with Different Percentage of Fly Ash Replacement.

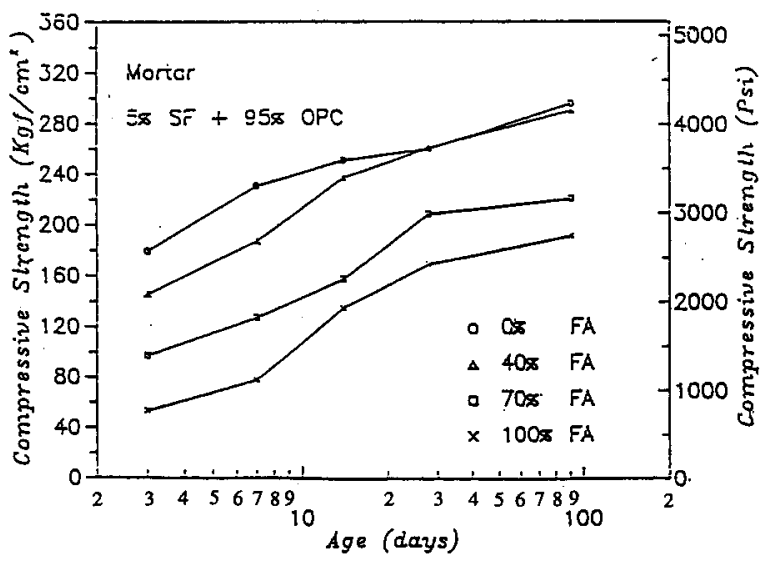

Fig. 2. Compressive Strengths of motars with Different Percentage of Fly Ash Replacement.

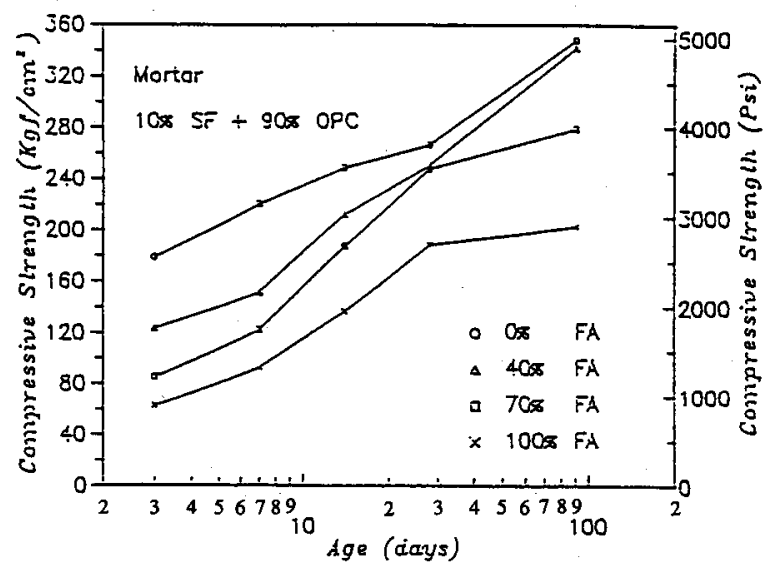

Fig. 3. Compressive Strengths of Motars with Different Percentage of Fly Ash Replacement.

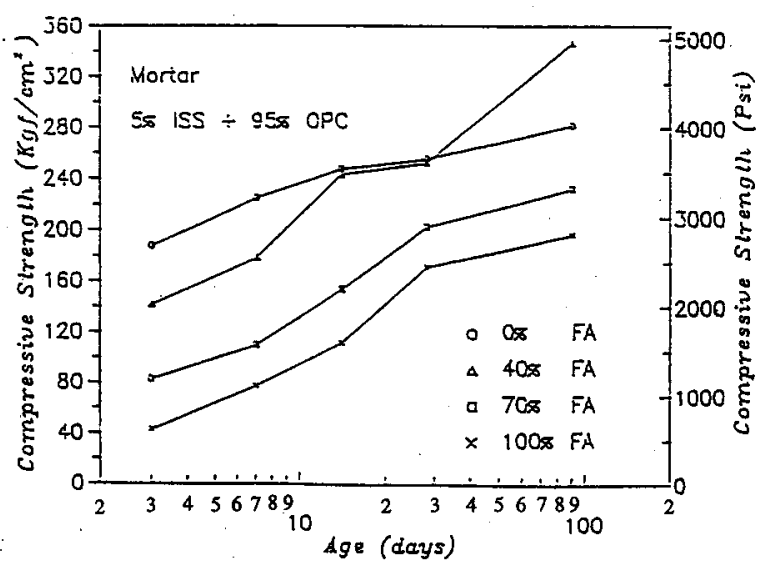

Fig. 4. Compressive Strengths of Motars with Different Percentage of Fly Ash Replacement.

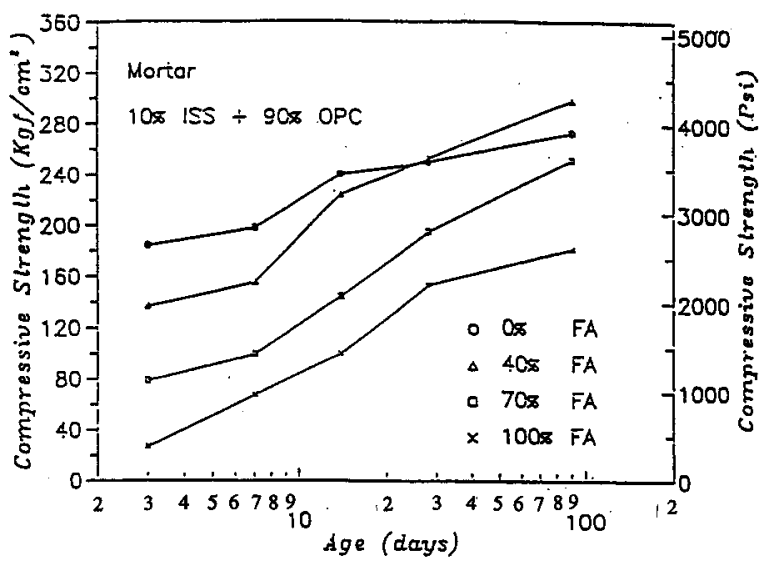

Fig. 5. Compressive Strengths of Motars with Different Percentage of Fly Ash Replacement.

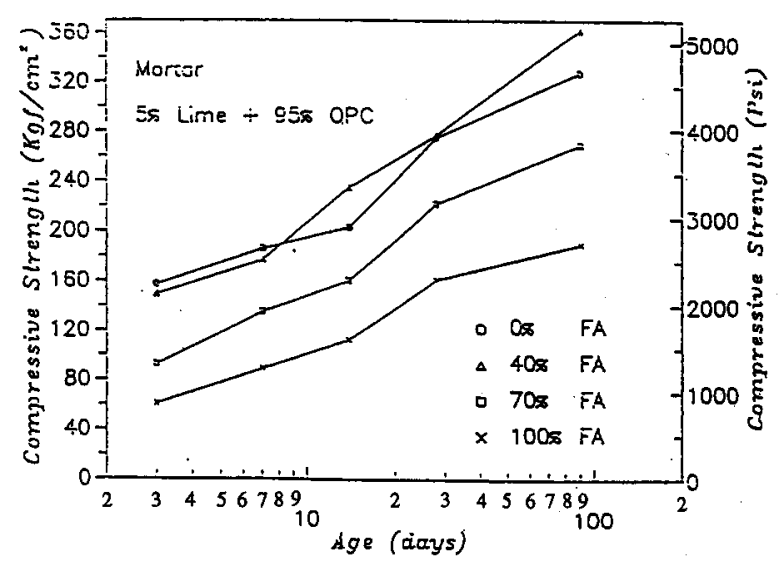

Fig. 6. Compressive Strengths of Motars with Different Percentage of Fly Ash Replacement. 


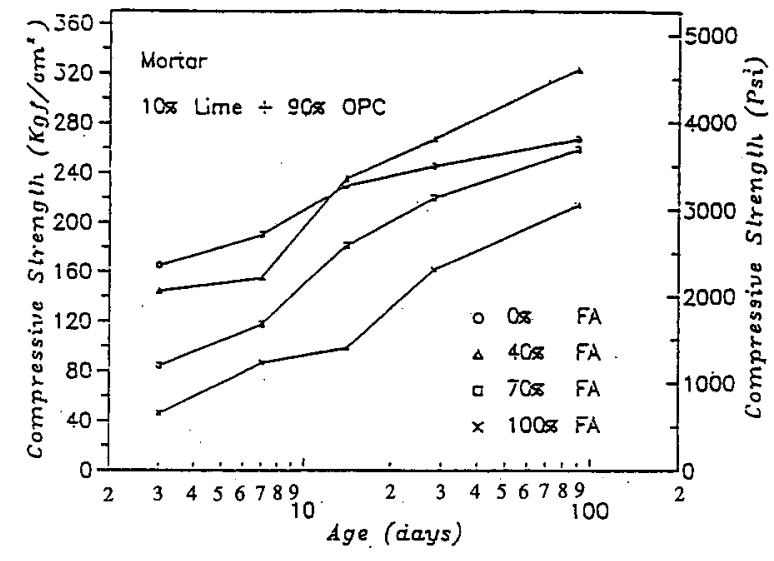

Fig. 7. Compressive Strengths of Motars with Different Percentage of Fly Ash Replacement.

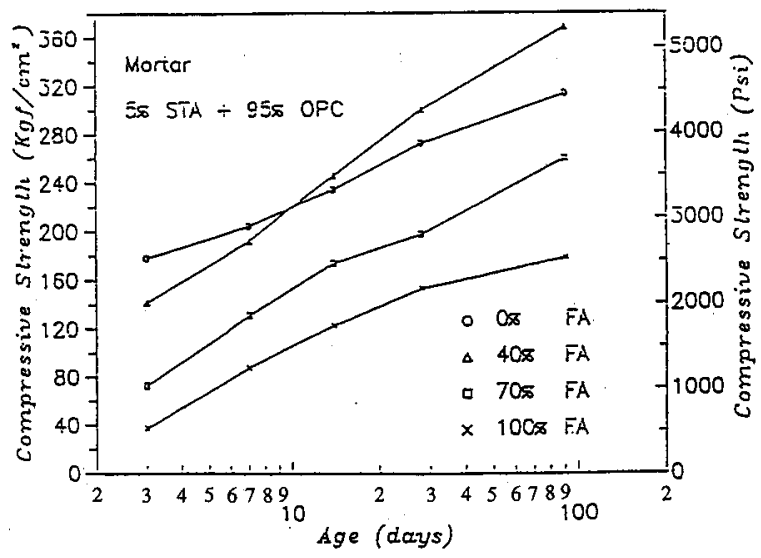

Fig. 8. Compressive Strengths of Motars with Different Percentage of Fly Ash Replacement.

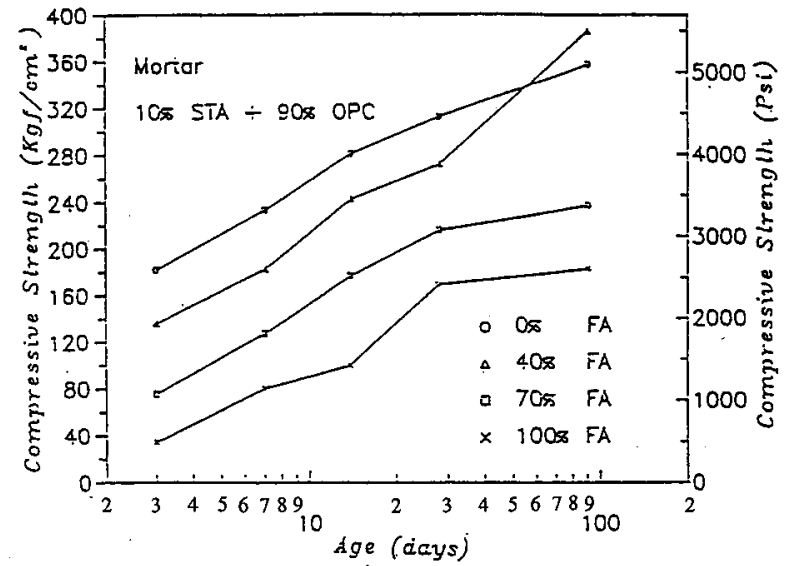

Fig. 9. Compressive Strengths of Motars with Different Percentage of Fly Ash Replacement.

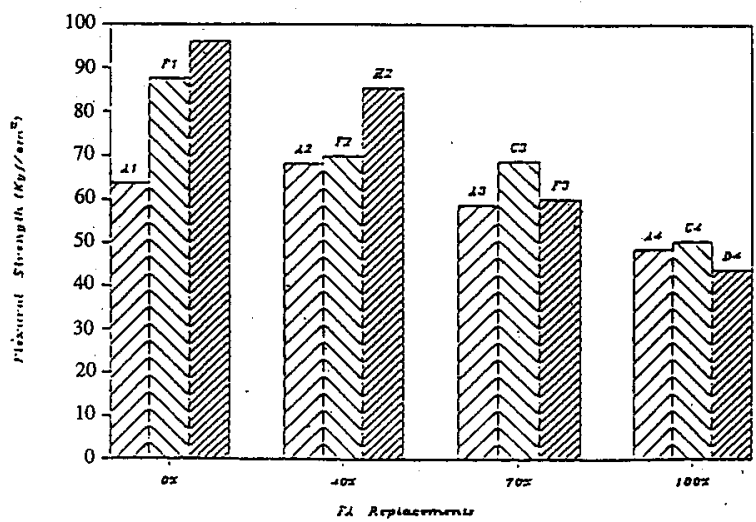

Fig. 10. Comparative Diagram for Flexural Strengths of Motars.

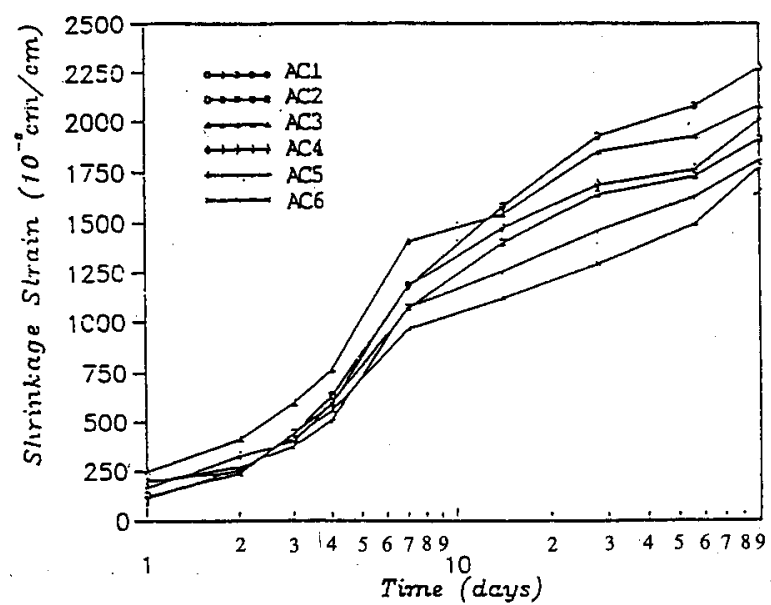

Fig. 11. Diagram of Shrinkage Strains vs Time for Different Fly Ash Mixes.

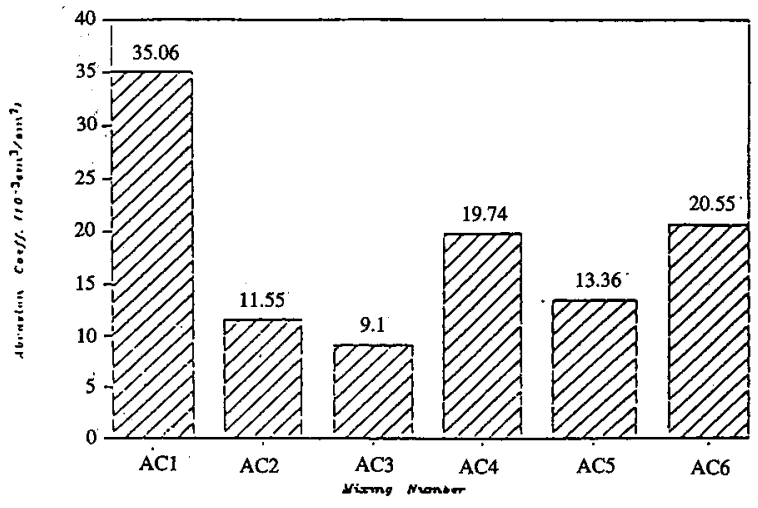

Fig. 12. Abrasion Coefficients for Different Fly Ash Mixes. 
2. The drying shrinkage of fly ash blocks are much larger than ordinary fly ash concrete. Bleeding is very prominent in the early age of fly ash blocks.

3. Natural sand used as constituent part of the mixes may improve the strength.

4. The leaching of the block's soluble components is so low within the range of this study that the solid blocks may be environmentally acceptable in the seawater.

5. Based on the 90-day strength, fly ash blocks may be applied to the secondary structure members for marine engineering.

6. From the viewpoint of engineering economy, overall physical performance, and environmental protection, the engineering application of the fly ash blocks should be considered and promoted. However, supplementary field testings are needed to assure the longterm performance for more applications.

\section{REFERENCES}

1. "The Study of Ash Utilization", Technical Report, Power Research Institute, Taiwan Power Company,
Vol. 2, 1987, pp. 1-87.

2. N. Bolt and A. Snel, "Environmental Aspect of Fly Ash Application in The Netherlands", Kema Scientific \& Technical Report, Vol. 4, No. 11, 1986, pp. 125-140.

3. M.N. Aaque, B.W. Langan, and M.A. Ward, "High Fly Ash Concrete", ACI Journal, Title No. 81-84, Jan.-Feb. 1984, pp. 54-60.

4. D. Ravina and P. K. Metha, "Compressive Strength of Low Cement/High Fly Ash Concrete", Cement and Concrete Research, Vol. 18, 1988, pp. 571-583.

5. S.T. Kuo, "Solidification of Fly Ash with Other Industrial Waste Materials", Proceeding of the Seventh International Ash Utilization Symposium and Exposition, Vol. 2, 1985, pp. 402-417.

6. S.B. Lee, "A Study of the Utilization of Industrial Waste Materials", Proceedings of the First National Symposium on the Treatment and Utilization of Industrial Waste Materials, Taiwan, 1985, pp. 1-10.

7. K. Yeh, "Pozzolanic Reaction of Coal Ashes", TaiPower Engineering Monthly, No. 428, 1984, pp. 2025 . 